\title{
Phytochemical and pharmacological properties of Curcuma aromatica Salisb (wild turmeric)
}

\author{
Nura Muhammad Umar ${ }^{1}$, Thaigarajan Parumasivam ${ }^{1 *}$, Nafiu Aminu², Seok-Ming Toh ${ }^{1}$ \\ ${ }^{1}$ School of Pharmaceutical Sciences, Discipline of Pharmaceutical Technology, Universiti Sains Malaysia (USM), 11800, Pulau Pinang, Malaysia. \\ ${ }^{2}$ Department of Pharmaceutics and Pharmaceutical Microbiology, Faculty of Pharmaceutical Sciences, Usmanu Danfodiyo University, Sokoto, Nigeria.
}

\section{ARTICLE INFO \\ Received on: 11/06/2020 \\ Accepted on: 04/08/2020 \\ Available online: 05/10/2020}

\section{Key words:}

Pharmacological activity, phytochemical constituents, Curcuma aromatica, Zingiberaceae.

\begin{abstract}
Curcuma aromatica Salisb. (C. aromatica) is commonly known as wild turmeric. Curcuma aromatica is an essential herbal plant and it has been extensively used in traditional medicine for centuries. It has been used for the treatment of gastrointestinal ailments, arthritic pain, inflammatory conditions, wounds, skin infections, and insect bites. This article aims to review the phytochemical and pharmacological aspects of C. aromatica and to provide a guide and insight for further studies. Electronic repositories, including Web of Science, Google Scholar, ProQuest, Science Direct, Scopus, and PubMed, were searched until December 2019 to identify studies relating to C. aromatica. A systematic analysis of the literature on pharmacognostical, physicochemical, and nutritional contents, bioactive compounds, and biological activities of $C$. aromatica was carried out, and ideas for future studies were also coined. A total of 157 articles concerning in vitro or in vivo (or both) researches on C. aromatica have been evaluated. Analyses of the data showed that $C$. aromatica consists of various classes of compounds, including alkaloids, flavonoids, curcuminoids, tannins, and terpenoids, that formed the bases of its pharmacological activities. The reviewed data also revealed that $C$. aromatica possessed the pharmacological effect of anticancer, antidiabetic, antioxidant, anti-inflammatory, antimicrobial, antitussive, antiepileptic, analgesic, wound healing, and insect repellent activities. This review has systematically compiled and summarized the literature related to the nutritional values and bioactive compounds, as well as the biological activities of $C$. aromatica. To the best of our knowledge, this is the most comprehensive review reported on C. aromatica.
\end{abstract}

\section{INTRODUCTION}

Curcuma aromatica Salisb. (C. aromatica) is known as "vanaharidra" in Ayurveda, wild turmeric in English, "jangli haldi" in Hindi, and "Yu Jin" in Chinese. It is commonly used as a coloring and flavoring agent, as well as in many traditional medicines in Southeast Asian countries (Kanase and Khan, 2018). Therapeutically, it possesses a strong antimicrobial effect and has been used since ancient times as a remedy against various microbial infections (Ahmed et al., 2008). The rhizomes of $C$. aromatica are used in traditional medicine for eliminating blood stasis, delaying the ageing process, pain relief, and protecting

\footnotetext{
*Corresponding Author

Thaigarajan Parumasivam, School of Pharmaceutical Sciences, Discipline of Pharmaceutical Technology, Universiti Sains Malaysia (USM), 11800, Pulau Pinang, Malaysia.E-mail: thaigarp@usm.my
}

against liver diseases (Dosoky and Setzer, 2018). Also, the rhizomes of $C$. aromatica are used internally as a tonic and carminative, while being topically applied for various skin ailments, sprains, bruises, as an antidote for snake venom, and also to enhance complexion (Ahmad et al., 2011; Dosoky and Setzer, 2018; Preethi et al., 2010; Xiang et al., 2017). Villagers in the northeastern part of India are using aqueous extracts and paste (with milk) of C. aromatica rhizomes and leaves for the treatment of indigestion, rheumatism, wound healing, and dysentery and also in the prevention of helminth infections (Sikha et al., 2015). In Thailand, the rhizome and roots of C. aromatica are often used in cosmetics and spas for skincare (Choochote et al., 2005). The traditional uses of $C$. aromatica rhizome extract as medicine are now being explored in modern scientific research for the possible development of modern medicine including but not limited to antimicrobial, antioxidant, anti-inflammatory, anticancer, antidiabetic, antiangiogenic, antitussive, antiobesity, antiacne, 
antiallergic, and wound healing (Pant et al., 2013; Preethi et al., 2010; Revathi and Malathy, 2013).

The rhizome of $C$. aromatica has been reported to be rich in medically essential phytochemicals, such as alkaloids, flavonoids, curcuminoids, tannins, and terpenoids (Anoop, 2015; Kanase and Khan, 2018). As this plant has considerable therapeutic potential, the extraction and characterization of the essential bioactive compounds with vital medicinal properties may provide opportunities relating to pharmaceutical applications. Therefore, in this review, we have compiled and critically analyzed the reported studies on the phytochemical and pharmacological properties of $C$. aromatica rhizomes, leaves, and its essential oil. We hope this will provide future insight into the medical application of $C$. aromatica for the treatment of various diseases.

\section{Botanical description}

Curcuma aromatica, commonly known as wild turmeric, belongs to family Zingiberaceae and genus Curcuma. The genus Curcuma consists of 70-100 species that are generally rhizomatous herbs and are well known for their therapeutic potential (Ahmed et al., 2008). The most commonly found species are Curcuma longa Linn., C. aromatica Salisb., Curcuma amada Roxb., Curcuma angustifolia Roxb., Curcuma caesia Roxb., and Curcuma zedoaria Rosc. found in various regions of the world (Sikha et al., 2015). C. aromatica is only second to C. longa (turmeric) as the crucial species of the family (Ahmed et al., 2008; Shivalingu et al., 2016). C. aromatica is widely distributed in tropical and subtropical regions and mostly cultivated for its rhizomes mainly in India, China, and Japan (Ahmed et al., 2008; Sikha et al., 2015). Curcuma aromatica is an annual, erect herb with a characteristic light yellow aromatic rhizome and camphoraceous smell (Anoop, 2015). The plant develops clumps of erect, unbranched leaf stems that on full growth can reach a height of about $1 \mathrm{~m}$ from the stout, underground rhizome and with enlarged colored bracts tipped with pink. The inflorescences usually appear from the base of the rhizomes (Fig. 1A) before the leaves are produced in early spring. The flowers are fragrant and pinkish-white with an orange lip. The plant grows fast, wild, and vigorously in the monsoon season. The foliage dries in late autumn and the rhizomes remain dormant in winter; the rhizome (Fig. 1B), when mature, possesses a characteristic fragrance (Schultes, 1991).

\section{Nutritional and physiochemical contents}

Rhizomes are the main edible portions of $C$. aromatica. They are well known for their high nutritional value and are particularly rich sources of carbohydrates, proteins, alkaloids, flavonoids, vitamin $\mathrm{C}$, beta-carotene, polyphenol, fatty acid, and essential oils (Ravindran et al., 2007). The rhizomes of C. aromatica are mainly used as a spice and food flavoring, as well as a coloring agent in food preparation due to their pleasant aroma and taste (Rajkumari and Sanatombi, 2018). The nutritional compositions of the rhizomes are crude protein (19.44\%), lipid (2.5\%), and carbohydrate $(97.5 \%)$. The rhizomes also have a moisture content of $19 \%$ and an ash content of $3.21 \%$ (Jain and Parihar, 2017). Other physicochemical parameters reported elsewhere were ash content $(16.6 \%$ total ash, $2.8 \%$ acid insoluble ash, and $3.93 \%$ water-soluble ash), extractive values $(0.4 \%$ alcohol soluble extractive value and $0.8 \%$ water-soluble extractive value), and moisture content (3.14\%) (Jain et al., 2016).

\section{Phytochemical constituents}

Qualitative and quantitative phytochemical analyses on different parts of $C$. aromatica are obtained via various extraction methods, and solvents are reported to commonly contain several essential classes of phytochemical compounds, including alkaloids, terpenoids, flavonoids, steroids, saponins, tannins, phenols, phytosterols, glycosides, protein amino acids, and volatile oils (Patil et al., 2019; Promod, 2018; Srividya et al., 2012).

The total phenolic content of the rhizome extracts of $C$. aromatica is reported in the range of $151.33 \pm 13.9 \mu \mathrm{g} / \mathrm{mg}$ eq to gallic acid (Jain and Parihar, 2017) to $265 \pm 1.08 \mathrm{mg} / \mathrm{g}$ of ascorbic acid (Srividya et al., 2012), and the total flavonoids content ranges

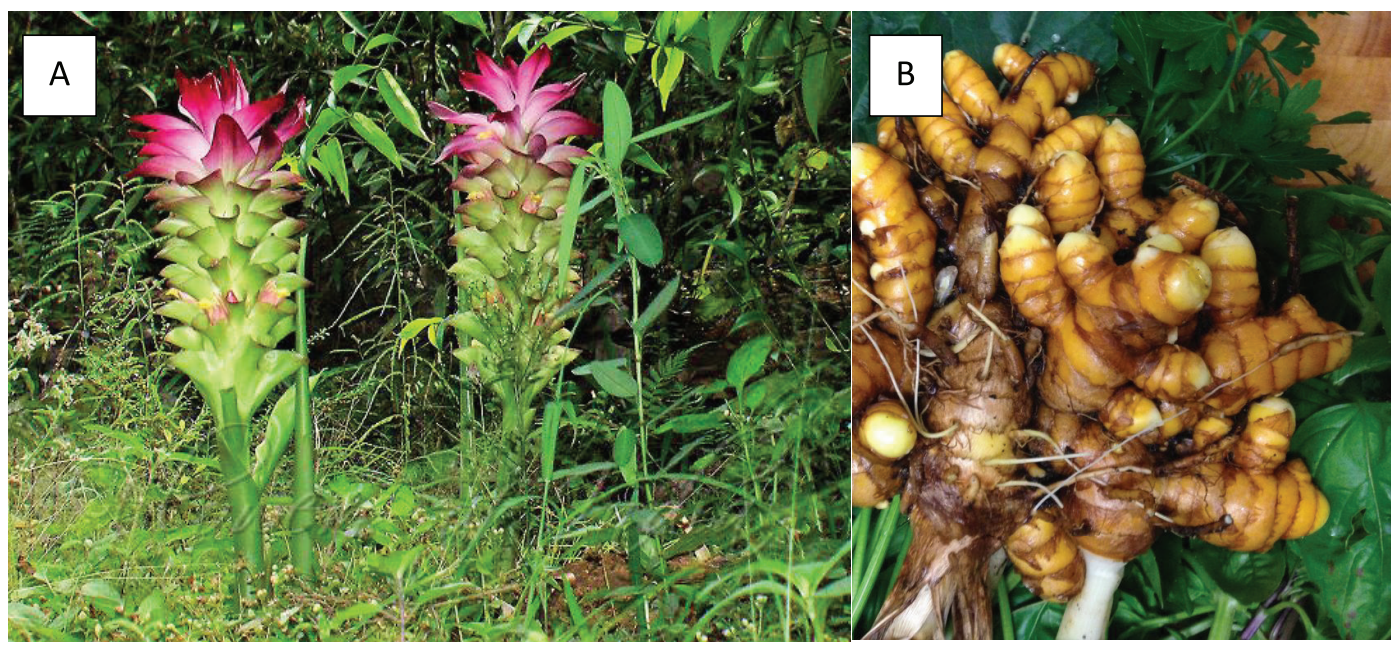

Figure 1. (A) Flowering cone of C. aromatica in its natural habitat (source: http://www.flowersofindia.net/catalog/slides/ Wild\%20Turmeric.html) and (B) fresh rhizomes of C. aromatica (source: https://www.gardentara.com/growing-organicturmeric/). 
from $106.8 \pm 2.76 \mu \mathrm{g} / \mathrm{mg}$ eq to quercetin (Jain and Parihar, 2017) to $175 \pm 1.56 \mathrm{mg} / \mathrm{g}$ of rutin (Srividya et al., 2012).

Thus, the presence of the above-mentioned phytochemicals shows the protective and disease preventive nature of the plant. It is also noteworthy to mention that there are not many phytochemical studies on the leaves of $C$. aromatica compared to other Curcuma species (i.e., C. caesia, C. longa, C. amada, and Curcuma xanthorrhiza) (Neha et al., 2013; Saxena and Sahu, 2012; Seema and Kaur, 2016).

\section{Bioactive compounds}

The bioactive compounds isolated and identified from the extracts and essential oils of $C$. aromatica obtained from different extraction methods are tabulated in Table 1 and 2, respectively. The chemical structures of some of the main bioactive compounds are shown in Figure 2. From the last three decades (1987-2019), a

Table 1. Major compounds isolated from solvent extracts of leaves and rhizomes of $C$. aromatica.

\begin{tabular}{|c|c|c|}
\hline Compounds isolated $(\geq \mathbf{5 \%})$ & $\begin{array}{l}\text { Extraction } \\
\text { method }\end{array}$ & References \\
\hline n-Heneitriacontan-14-one & \multirow[t]{5}{*}{$\mathrm{SE}$} & \multirow[t]{5}{*}{ Ahmad et al. (2011) } \\
\hline Stigmasterol & & \\
\hline n-Nonacosan-1-ol & & \\
\hline n-Pentatriacontan-5-one & & \\
\hline Curcumapentadecanol & & \\
\hline Curcumin & \multirow[t]{12}{*}{$\mathrm{CM}$} & \multirow{12}{*}{$\begin{array}{l}\text { Bamba et al. (2011); } \\
\text { Tsai et al. (2018) }\end{array}$} \\
\hline Isozedoarondiol & & \\
\hline Zedoarondiol & & \\
\hline Aerugidiol & & \\
\hline Demethoxycurcumin & & \\
\hline Epiprocurcumenol & & \\
\hline Isoprocurcumenol & & \\
\hline 13-hydroxy-germacrone & & \\
\hline (2S)-2-hydroxycurdione & & \\
\hline$(4 \mathrm{~S}, 5 \mathrm{~S})-(+)$-germacrone4,5-epoxide & & \\
\hline Procurcumenol & & \\
\hline Curcumenone & & \\
\hline Curdione & \multirow[t]{5}{*}{ SE } & \multirow[t]{5}{*}{ Huang et al. (2000) } \\
\hline Neocurdione & & \\
\hline Curcumol & & \\
\hline (R)-(+)-1,2-hexadecanediol & & \\
\hline Tetramethylpyrazine & & \\
\hline Curcumene & \multirow[t]{2}{*}{$\mathrm{CM}$} & \multirow[t]{2}{*}{ Choochote et al. (2005) } \\
\hline 1H-3a,7-methanoazulene & & \\
\hline Aromaticanoid (A to E) & SE & Dong et al. (2018) \\
\hline Germacrone & \multirow[t]{2}{*}{$\mathrm{CM}$} & \multirow[t]{2}{*}{ Pintatum et al. (2020) } \\
\hline Dehydrocurdione & & \\
\hline Zederone & \multirow[t]{2}{*}{$\mathrm{CM}$} & \multirow[t]{2}{*}{ Pant et al. (2001) } \\
\hline$\beta$-Sitosterol & & \\
\hline$\beta$-Sitosterol-3- $O$ - $\beta$-D-glucopyranoside & SE & Pant et al. (2013) \\
\hline Vatirenene & \multirow[t]{2}{*}{ SE } & \multirow[t]{2}{*}{ Revathi and Malathy (2013) } \\
\hline Androstan-17-one-3-ethyl-3-hydroxy(5à) & & \\
\hline
\end{tabular}

$\mathrm{SE}=$ Soxhlet extraction $; \mathrm{CM}=$ cold maceration total of 79 major compounds have been identified from the leaves, rhizomes, and essential oils of $C$. aromatica. Most of the major compounds belong to alkaloids, flavonoids, curcuminoids, tannins, and terpenoids. Interestingly, there is no significant difference between the compounds found in the extracts of the leaves and rhizomes or their essential oils of $C$. aromatica grown either in the same or in different regions. A total of 37 (Table 1) compounds have been isolated and identified in the solvents extracts of leaves and rhizomes of $C$. aromatica. An additional 42 compounds were isolated and identified in the essential oils from the leaves and rhizomes (Table 2). The essential oils were also reported to have more potent antimicrobial, antioxidant, anticancer, and anti-inflammatory activities than the solvent extract counterparts (Xiang et al., 2018).

\section{Pharmacological activities of $C$. aromatica}

Various studies have been reported on the pharmacological activities of $C$. aromatica as summarized below and in Table 3.

\section{Anticancer activity}

Cancer is a disease characterized by an uncontrollable growth of cells in the human body, forming tumors of malignant cells (Greenwell and Rahman, 2015). Cancer is a major public health problem and the second leading cause of death in both developed and developing countries (Moraes et al., 2017). The current regimen, including surgery, chemotherapy, and radiotherapy, is often expensive and associated with severe side effects (Greenwell and Rahman, 2015). Hence, the focus has shifted to identifying new, safe, and cost-effective alternative treatment against cancer, preferably from natural sources. Bioactive compounds, including 1,8-cineole, ar-curcumene, ar-turmerone, $\beta$-elemene, camphor, curcumol, curdione, germacrone, linalool, xanthorrhizol, and zingiberene, from the essential oil of $C$. aromatica have been proven to possess anticancer properties.

Xiang et al. (2018) studied cytotoxic activities of essential oils extracted from the rhizomes of $C$. aromatica by colorimetric MTT [3-(4,5-dimethyl-2-thiazolyl)-2,5diphenyltetrazolium bromide] assay against prostate cancer cells line [lymph node carcinoma of the prostate (LNCaP)] and human hepatoma cells line (HepG2). The essential oils showed significantly higher anticancer activity against $\mathrm{LNCaP}\left(\mathrm{IC}_{50}\right.$ of $1.14 \pm 0.02 \mu \mathrm{g} / \mathrm{ml})$ than the HepG2 $\left(\mathrm{IC}_{50}\right.$ of $168.94 \pm 1.93 \mu \mathrm{g} /$ $\mathrm{ml})$. In another study, the infusion of essential oils via the hepatic artery exhibited rapid therapeutic effects in patients with primary liver cancer and transplanted hepatoma rat model, respectively (Cheng et al., 1999). The essential oils were also reported to have a protective effect against intestinal metaplasia and esophagoduodenal anastomosis in a rat model (Li et al., 2009). On the other hand, Hou et al. (2011) investigated the inhibitory effect of curdione isolated from the rhizome of $C$. aromatica on CYP3A4 using 1 $\alpha, 25-(\mathrm{OH})(2)-\mathrm{D}(3)$-treated Caco-2 clone cells. The results revealed that curdione showed the best inhibitory activity with $\mathrm{IC}_{50}$ of $3.9 \mu \mathrm{g} / \mathrm{ml}$ after 72 hours of treatment with no cytotoxic effect. Hence, it was concluded that the inhibitory activity of curdione accelerates the degradation of CYP3A4. The molecular mechanisms of apoptotic activity of curcumin 
<smiles>C=C1C2CCC(C2)C1(C)C</smiles>

Camphene

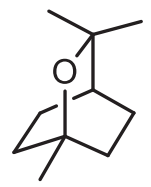

1,8-Cineole<smiles>CC12CCC(CC1=O)C2(C)C</smiles>

Camphor<smiles>CC1(C)C2CC(O)C1(C)C2(C)C</smiles>

Borneol<smiles>C/C=C\CC(=O)[C@@H](CCCC)CC(=O)C(C)C</smiles>

Curdione<smiles>C=CC1(C)CCC(C(=C)C)CC1C(=C)C</smiles>

ß-elemene

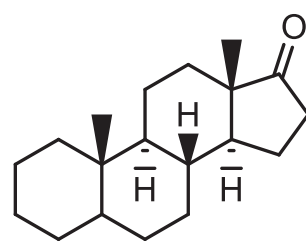

Androstan-17-one<smiles>CC(C)=CC(=O)CC(C)c1ccc(C)cc1</smiles><smiles>C=CC(C)(O)CCC=C(C)C</smiles><smiles>CC(C)=CCC[C@H](C)c1ccc(C)c(O)c1</smiles>

Xanthorrhizol

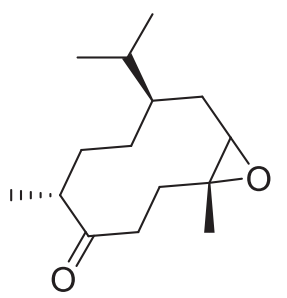

(4S,5S)-Germacrone 4,5-epoxide<smiles>C=C1C[C@]2(O)O[C@@]3(CC[C@H]23)C[C@H](C(C)C)[C@@H]1C</smiles>

Curcumol<smiles>CC(C)=CCC[C@@H](C)[C@H]1C=CC(C)=CC1</smiles>

Zingiberene<smiles>COc1cc(/C=C/C(=O)CC(=O)/C=C/c2ccc(O)c(OC)c2)ccc1O</smiles>

Curcumin<smiles>CC(C)=CCCC(C)c1ccc(C)cc1</smiles>

Ar-curcumene<smiles>COc1cc(/C=C/C(=O)CC(=O)/C=C/c2ccc(O)cc2)ccc1O</smiles>

Demethoxycurcumin<smiles>C=C1C=CC(C(C)CCC=C(C)C)CC1</smiles>

\section{ß-Sesquiphellandrene}

Figure 2. Chemical structures of some of the main bioactive compounds from extracts and essential oils from the leaves and rhizomes of $C$. aromatica. 
Table 2. Major compounds isolated from the essential oils of leaves and rhizomes of $C$. aromatica.

\begin{tabular}{|c|c|c|}
\hline Compounds isolated $(\geq \mathbf{5 \%})$ & Extraction method & References \\
\hline Ar-curcumene & SD & Xiang et al. (2018) \\
\hline \multicolumn{3}{|l|}{$\beta$-curcumene } \\
\hline \multicolumn{3}{|l|}{ Curzerene } \\
\hline \multicolumn{3}{|l|}{ Curzerenone } \\
\hline \multicolumn{3}{|l|}{ Zingiberene } \\
\hline Camphor & $\mathrm{HD}$ & Choudhury et al. (1996); \\
\hline 1,8-cineole & & $\begin{array}{l}\text { Gopichand et al. (2006); } \\
\text { Kasai et al. (2019); }\end{array}$ \\
\hline Germacrone & & Priyanka et al. (2019) \\
\hline \multicolumn{3}{|l|}{ Isoborneol } \\
\hline \multicolumn{3}{|l|}{ Camphene } \\
\hline \multicolumn{3}{|l|}{ Limonene } \\
\hline ar-turmerone & SD & Tsai et al. (2011) \\
\hline \multicolumn{3}{|l|}{ Humulene oxide } \\
\hline \multicolumn{3}{|l|}{$\beta$-selinene } \\
\hline P-cymene & HD & Singh et al. (2002) \\
\hline \multicolumn{3}{|l|}{$\alpha$-terpineol } \\
\hline \multicolumn{3}{|c|}{ 2-oxabicyclo $(3,2,1)$ octane-1-,4-dimethyl-8-methylene } \\
\hline Curcumene & $\mathrm{SD} / \mathrm{HD}$ & Choochote et al. (2005); \\
\hline \multicolumn{3}{|l|}{ 1H-3a, 7-methanoazulene } \\
\hline Caryo-phyllene oxide & $\mathrm{HD}$ & Al-Reza et al. (2010) \\
\hline \multicolumn{3}{|l|}{ Patchouli alcohol } \\
\hline \multicolumn{3}{|l|}{ Elsholtzia ketone } \\
\hline Borneol & $\mathrm{HD}$ & Al-Reza et al. (2011) \\
\hline \multicolumn{3}{|l|}{ Vinyldimethylcarbinol } \\
\hline \multicolumn{3}{|l|}{ Cubenol } \\
\hline \multicolumn{3}{|l|}{ Cucumber alcohol (2,6-Nonadien-1-ol) } \\
\hline Linalool & SDE & Tsai et al. (2011) \\
\hline \multicolumn{3}{|l|}{ Humulene oxide } \\
\hline \multicolumn{3}{|l|}{ Curcumol } \\
\hline Eucalyptol & SD & Chai et al. (2012) \\
\hline \multicolumn{3}{|l|}{ Neocurdione } \\
\hline Curdione & $\mathrm{HD}$ & Feng et al. (2013) \\
\hline \multicolumn{3}{|l|}{$\beta$ - elemene } \\
\hline \multicolumn{3}{|l|}{ Eugenol } \\
\hline Isoledene & $\mathrm{HD}$ & Angel et al. (2014); \\
\hline \multicolumn{3}{|r|}{ Lee et al. (2014) } \\
\hline \multicolumn{3}{|l|}{ Agarospirol } \\
\hline \multicolumn{3}{|l|}{$\alpha$-caryophyllene } \\
\hline \multicolumn{3}{|l|}{$\beta$-guaiene } \\
\hline$\beta$-sesquiphellandrene & SD & Herath et al. (2017); \\
\hline Ermanthin & & Xiang et al. $(2018,2017)$ \\
\hline 8,9-dehydro-9-formyl-cycloisolongifolene & & \\
\hline
\end{tabular}

isolated from $C$. aromatica were examined on human hepatoma SMMC-7721 cells (Yu et al., 2011). The curcumin significantly inhibited the growth of SMMC-7721 cells in a concentrationdependent manner and also induced apoptosis by modulation of apoptotic proteins (bax/bcl-2) in SMMC-7721 cells (Yu et al., 2011). A similar study by Dai et al. (2013) investigated the antiproliferative mechanism of the apoptotic effect of $\beta$-elemene isolated from $C$. aromatica on a HepG2 which revealed that $\beta$-elemene effectively inhibited the proliferation of HepG2 cells in a time- and dose-dependent manner. The induction of apoptosis in hepatoma HepG2 cells was by the upregulation of Fas/FasL expression. 
Table 3. Biological activities of the main bioactive compounds in the extracts and essential oils of C. aromatica.

\begin{tabular}{|c|c|c|}
\hline Bioactive compounds & Biological activity & References \\
\hline \multirow[t]{4}{*}{ 1,8-Cineole } & Analgesic & Takaishi et al. (2012); Zheng et al. (2019) \\
\hline & Anticancer & Murata et al. (2013); Sampath et al. (2017) \\
\hline & Antioxidant & Miri (2018); Torres-Martínez et al. (2017) \\
\hline & Insect repellent & Obeng-Ofori et al. (1997) \\
\hline Androstan-17-one & Antiepileptic & Kaminski et al. (2005) \\
\hline \multirow[t]{9}{*}{ Ar-Turmerone } & Anticancer & Kim et al. (2013); Park et al. (2012); Schmidt et al. (2015) \\
\hline & Antidiabetic & Lekshmi et al. (2012) \\
\hline & Anti-inflammatory & Jantan et al. (2012); Oh et al. (2014); Rana et al. (2015) \\
\hline & Antimicrobial & Amaral et al. (2014); Lee (2006) \\
\hline & Antimutagenic & Jayaprakasha et al. (2002) \\
\hline & Antivenom & Ferreira et al. (1992); Melo et al. (2005) \\
\hline & Chemopreventive & Yue et al. (2010) \\
\hline & Insect repellent & Ajaiyeoba et al. (2008); Ali et al. (2015) \\
\hline & Neuroprotective & Hucklenbroich et al. (2014) \\
\hline Ar-Curcumene & Anticancer & Schmidt et al. (2015) \\
\hline \multirow[t]{3}{*}{$\beta$-Elemene } & Anticancer & Jiang et al. (2016, 2017); Zhao et al. (2015) \\
\hline & Antiangiogenic & Chen et al. (2011) \\
\hline & Hepatoprotective & Liu et al. (2011) \\
\hline$\beta$-Sesquiphellandrene & Antioxidant & Zhao et al. (2010) \\
\hline \multirow[t]{2}{*}{ Borneol } & Analgesic & Xiong et al. (2013) \\
\hline & Anti-inflammatory & Almeida et al. (2013) \\
\hline \multirow[t]{2}{*}{ Camphene } & Analgesic & Quintans-Júnior et al. (2013) \\
\hline & Hypolipidemic & Vallianou et al. (2011) \\
\hline \multirow[t]{5}{*}{ Camphor } & Analgesic & Adams (2012) \\
\hline & Anticancer & Wu et al. (2016); Zhang et al. (2019) \\
\hline & Antimicrobial & Peng et al. (2012); Rahman et al. (2016) \\
\hline & Antitussive & Kumar et al. (2012); Laude et al. (1994) \\
\hline & Insect repellent & Chen et al. (2018); Fu et al. (2015) \\
\hline \multirow[t]{7}{*}{ Curcumin } & Anticancer & Allegra et al. (2017); Vallianou et al. (2015) \\
\hline & Anti-inflammatory & Bagad et al. (2013); Chandran and Goel, (2012) \\
\hline & Antimicrobial & \\
\hline & Antidiabetic & De Oliveira et al. (2018); Tyagi et al. (2015) \\
\hline & & Chuengsamarn et al. (2012); Roxo et al. (2019); Widowati et al. (2018) \\
\hline & Antiplatelet & Liu et al. (2013); Perrone et al. (2015) \\
\hline & Wound healing & Mirzahosseinipour et al. (2020); Mohanty and Sahoo (2017); Nguyen et al. (2019) \\
\hline \multirow[t]{2}{*}{ Curcumol } & Anticancer & Ning et al. (2016); Zhang et al. (2011) \\
\hline & Antidiabetic & Raafat and Omar (2016) \\
\hline \multirow[t]{3}{*}{ Curdione } & Anticancer & Li et al. (2014) \\
\hline & Neuroprotective & Li et al. (2017) \\
\hline & Antimicrobial & Naz et al. (2010) \\
\hline \multirow[t]{2}{*}{ Demethoxycurcumin } & Anti-inflammatory & Ramkumar et al. (2018) \\
\hline & Neuroprotective & Ramkumar et al. (2017) \\
\hline \multirow[t]{4}{*}{ Germacrone } & Anticancer & Wu et al. (2020); Ye et al. (2017) \\
\hline & Antimicrobial & Diastuti et al. (2014) \\
\hline & Antioxidant & Hamdi et al. (2015); Hossain et al. (2015) \\
\hline & Antiproliferative & Lim et al. (2016); Zhang et al. (2020) \\
\hline
\end{tabular}




\begin{tabular}{|c|c|c|}
\hline Bioactive compounds & Biological activity & References \\
\hline \multirow[t]{6}{*}{ Linalool } & Anticancer & Iwasaki et al. (2016); Rodenak-Kladniew et al. (2018); Sun et al. (2015) \\
\hline & Antiepileptic & Bahr et al. (2019); Souto-Maior et al. (2017) \\
\hline & Anti-inflammatory & Kim et al. (2019a); Lee et al. (2018) \\
\hline & Antioxidant & Jabir et al. (2018) \\
\hline & Antimicrobial & Wu et al. (2019) \\
\hline & Insect repellent & Campos et al. (2018); Fujiwara et al. (2017); Pajaro-Castro et al. (2017); Tabari et al. (2017) \\
\hline \multirow[t]{7}{*}{ Xanthorrhizol } & Anticancer & Nurcholis et al. (2018) \\
\hline & Antidiabetic & Kim et al. (2014) \\
\hline & Antihypertensive & Campos et al. (2000) \\
\hline & Anti-inflammatory & Kim et al. (2014) \\
\hline & Antimicrobial & Kim et al. (2019b); Yanti et al. (2009) \\
\hline & Antioxidant & Liao et al. (2019); Oon et al. (2015) \\
\hline & Antiplatelet & Jantan et al. (2008) \\
\hline \multirow[t]{4}{*}{ Zingiberene } & Anticancer & Chen et al. (2019); Chopra et al. (2019) \\
\hline & Antioxidant & Togar et al. (2015) \\
\hline & Antiulcer & Ko and Leung (2010) \\
\hline & Insect repellent & Eigenbrode and Trumble (2019) \\
\hline
\end{tabular}

\section{Antidiabetic activity}

Diabetes mellitus is a chronic, life-threatening systemic disease leading to multiple complications, such as blindness, kidney failure, amputations, strokes, and heart attacks (Meral et al., 2001). Diabetes mellitus causes oxidative destruction of cellular membranes and redox imbalance (within the cells) called oxidative stress (Cheeseman, 1993), which leads to an increased production of free radicals and a decreased antioxidant defense mechanism in the body. Hence, it has been hypothesized that, in diabetes mellitus, free radical production increases due to the increased oxidative stress and decreased antioxidant production (Ahmad et al., 2014; Meral et al., 2001). Thus, the increased production of free radicals could be considered as one of the significant complications of diabetes mellitus (Meral et al., 2001). Curcuma aromatica possesses compounds such as 1,8-cineole (Miri, 2018; Saito et al., 2004), ar-turmerone (Lekshmi et al., 2012), curcumin (Chuengsamarn et al., 2012; Roxo et al., 2019; Widowati et al., 2018), curcumol (Raafat and Omar, 2016), demethoxycurcumin (Jayaprakasha et al., 2006), germacrone (Hamdi et al., 2015; Hossain et al., 2015; Makabe et al., 2006), and xanthorrhizol (Kim et al., 2014) that have been well reported to have antioxidant and antidiabetic properties. Besides, Srividya et al. (2012) reported that the toluene extract of rhizomes of $C$. aromatica significantly decreased the glucose level from 278.53 to $116.5 \mathrm{mg} / \mathrm{dl}$, increased protein level from 3.09 to $5.78 \mathrm{mg} / \mathrm{dl}$, decreased cholesterol level from 292.33 to $134.50 \mathrm{mg} / \mathrm{dl}$, and reduced the triglyceride level from 85.66 to $64.16 \mathrm{mg} / \mathrm{dl}$ upon oral administration at a maximum single dose of $400 \mathrm{mg} / \mathrm{kg}$ in streptozotocin-induced diabetic rats.

\section{Antioxidant activity}

An antioxidant is a molecule that scavenges and neutralizes free radicals by donating an electron, thus reducing the damaging power of free radicals (Halliwell, 1995). Methanol and aqueous extracts of $C$. aromatica rhizomes have been proven to have comparable potency to $L$-ascorbic acid, a well-known antioxidant with $\mathrm{IC}_{50}$ less than $60 \mu \mathrm{g} / \mathrm{ml}$. In another study, Xiang et al. (2017) studied the antioxidative activity of the essential oils of C. aromatica rhizomes from 12 different locations in China using the 2,2diphenyl-1-picrylhydrazyl (DPPH) radical-scavenging assay. The results again proved the antioxidative potency of $C$. aromatica with $\mathrm{IC}_{50}$ ranging from 1.57 to $21.36 \mu \mathrm{g} / \mathrm{ml}$, which was indeed better than the control, Trolox $\mathrm{C}\left(\mathrm{IC}_{50} 8.82 \mu \mathrm{g} / \mathrm{ml}\right)$.

Similarly, Al-Reza et al. (2010) studied the chemical composition and antioxidative activity of both essential oil and organic extracts of $C$. aromatica leaves. The antioxidant properties were evaluated by DPPH and superoxide radical-scavenging assays. The essential oil extract showed potent antioxidative activity $\left(\mathrm{IC}_{50}=14.45 \mu \mathrm{g} / \mathrm{ml}\right)$, followed by the methanol extract $\left(\mathrm{IC}_{50} 16.58 \mu \mathrm{g} / \mathrm{ml}\right.$ ), and both possessed better activity than the reference compound, butylated hydroxyanisole with an $\mathrm{IC}_{50}$ value of $18.27 \mu \mathrm{g} / \mathrm{ml}$. The activity was associated with the presence of antioxidant compounds such as 1,8-cineole (Miri, 2018; Saito et al., 2004), germacrone (Hamdi et al., 2015; Hossain et al., 2015), xanthorrhizol (Liao et al., 2019; Oon et al., 2015), and $\beta$-sesquiphellandrene (Zhao et al., 2010).

\section{Antimicrobial activity}

Microbial contamination and resistance are a few of the significant challenges in the food, beverage, and pharmaceutical industries. For instance, antimicrobial agents, including food preservatives, have been used to inhibit the growth of food-borne bacteria and prolong the shelf life of processed foods (RahimiNasrabadi et al., 2013). Many plant derivatives, including those of $C$. aromatica, have been shown to possess antimicrobial properties.

A study conducted by Revathi and Malathy (2013) revealed that crude hexane extract of $C$. aromatica was effective against Gram-positive bacteria and ineffective against the tested Gram-negative bacteria. The phytochemical analysis identified that the antimicrobial activity was attributed to germacrone. 
It should be noted that germacrone has also been reported to possess other biological activities, including anti-inflammatory, antitussive, antitumor, and antifungal properties (Wu et al., 2017). On the other hand, the essential oil extracted from the fresh rhizomes of $C$. aromatica has been shown to inhibit the growth of both Gram-positive and Gram-negative bacteria (Ahmed et al., 2008). Curcumin (diferuloylmethane) was then isolated and found to be active against Staphylococcus aureus strains and Saccharomyces cerevisiae. In another study, the essential oil of $C$. aromatica was also reported to have higher antifungal activity against $S$. cerevisiae $(183.18 \mu \mathrm{g} / \mathrm{ml})$ than the essential oils from other Curcuma species, including Curcuma nankunshanensis, Curcuma elata, Curcuma kwangsiensis var. nanlingensis, Curcuma yunnanensis, Curcuma rubescens, and Curcuma sichuanensis (Xiang et al., 2018).

Apart from germacrone and curcumin, C. aromatica is also composed of other bioactive compounds, such as ar-turmerone (Dhingra et al., 2007; Lee, 2006), camphor (Kordali et al., 2005; Kotan et al., 2008; Viljoen et al., 2003; Zafar et al., 2019), curdione (Naz et al., 2010), linalool (Queiroga et al., 2007; Van Zyl et al., 2006), and xanthorrhizol (Hwang et al., 2000; Rukayadi and Hwang, 2007; Rukayadi et al., 2006), that are reported elsewhere to have an antimicrobial effect against both fungi (Aspergillus flavus, Fusarium semitectum, Colletotrichum gloeosporioides, Colletotrichum musae, Candida albicans, Candida glabrata, Candida guilliermondii, Candida krusei, Candida parapsilosis, and Candida tropicalis) and bacteria (Escherichia coli, S. aureus, and Bacillus cereus). Perhaps these findings are not surprising, as $C$. aromatica often is one of the ideal plant sources for the treatment of various infectious diseases in the conventional and Ayurvedic regime.

\section{Anti-inflammatory activity}

Inflammation has been described as a transitory biological tissue response to dangerous stimuli, for example, wounds, exogenic, and endogenic antigens, meant to clear or remove the stimulus and repair the wounded tissue that ultimately leads to tissue regeneration and normal homeostasis (Egger, 2012). Even though inflammation is an affirmative body defense mechanism, dysregulated and chronic inflammatory reactions have been well documented as underlying causes of many systemic diseases, including diabetes, asthma, atherosclerosis, obesity, cancer, and pain, thus contributing to the increased cost of healthcare to the society (Mizuno et al., 2011).

However, an undeniable fact is that most of the conventional nonsteroidal anti-inflammatory drugs (NSAIDs), steroids, and immunosuppressant drugs used to treat all kinds of inflammatory conditions are linked with unfavorable side effects, such as headache, ulceration, gastric irritation, perforation, hemolytic anemia, hyperglycemia, and many more (Bagad et al., 2013). Considering these drawbacks associated with these drugs, an alternative source especially from medicinal plants that are usually considered safe is incessantly being investigated for probable anti-inflammatory activity.

Xiang et al. (2017) studied the anti-inflammatory activity of the essential oils of $C$. aromatica rhizomes obtained from 12 different locations in China. In their study, ear edema was induced by 12-O-tetradecanolphorbol-13-acetate in mice. Different groups of mice received different essential oil treatments, and ibuprofen was used as a positive control. Generally, all the essential oils showed anti-inflammatory activity on a dose-dependent fashion from 20.56 to $61.34 \%$ and surprisingly superior to ibuprofen $(17.84 \%-54.57 \%)$, which is known for its anti-inflammatory effect. The histological and immunohistochemical analysis further showed tissue relief from inflammation after treatment with both essential oils. Cytokine analysis showed a significant decrease in the expression of COX2 and TNF- $\alpha$ in the essential oil-treated groups compared to the untreated group. However, the difference was not significant compared to the ibuprofen-treated group. The extracts of $C$. aromatica rhizomes were also reported to have a promising anti-inflammatory effect similar to prednisolone when tested on the inflamed paw of mice induced by carrageenan (Ahmed et al., 2008).

It is not surprising though that the extracts and essential oil of $C$. aromatica have a more anti-inflammatory effect than conventional drugs, as they contain and may have a synergistic effect of different potent anti-inflammatory compounds, such as ar-turmerone (Jantan et al., 2012; Oh et al., 2014; Rana et al., 2015), borneol (Almeida et al., 2013), curcumin (Bagad et al., 2013; Chandran and Goel, 2012), curdione (Oh et al., 2007), linalool (Peana et al., 2002), 1,8-cineole (Beer et al., 2017), and xanthorrhizol (Chung et al., 2007; Lee et al., 2002; Lim et al., 2005).

\section{Antitussive activity}

One study has reported on the antitussive activity of $C$. aromatica. Marina et al. (2008) revealed that the ethanol extract of the plant possessed a promising and comparable antitussive effect with codeine phosphate in a dose-dependent fashion. The extract inhibited $79 \%$ of cough at a concentration of $400 \mathrm{mg} / \mathrm{kg}$ body weight after 1.5 hours of oral administration, which is similar to codeine phosphate ( $87 \%$ at a concentration of $40 \mathrm{mg}$ ) in mice. The acute oral toxicity study of the ethanol extract showed no adverse effect up to the maximum dose of $4 \mathrm{~g} / \mathrm{kg}$.

\section{Analgesic activity}

The use of analgesic drugs, such as opiates and NSAIDs, for pain relief has been stagnated as these drugs are reported to have adverse side effects, including addiction and gastrointestinal disorders (Khokra et al., 2012; Maniyar and Sriraj, 2017). In an effort to find natural alternatives to these drugs, several plants, including $C$. aromatica, have been studied and have showed potent analgesic activity. Pranav Kumar et al. (2013) studied the analgesic effect of aqueous extract of $C$. aromatica rhizomes by Eddy's hot plate $\left(55^{\circ} \mathrm{C}\right)$ method in rats to induce pain due to heat. The extract was administered orally at a concentration of 300 and $500 \mu \mathrm{g} / \mathrm{kg}$ and showed prolonged pain latency compared to the diclofenac sodium $(10 \mathrm{mg} / \mathrm{kg})$. In another study, a reduced number of writhes by mice were observed in the acetic acid-induced writhing test after the administration of aqueous extract of the rhizomes of C. aromatica (Huang et al., 2007). The analgesic activity of $C$. aromatica was attributed to the presence of 1,8-cineole (Takaishi et al., 2012; Zheng et al., 2019), linalool (Souto-Maior et al., 2017), borneol (Xiong et al., 2013), camphene (Quintans-Júnior et al., 2013), and camphor (Adams, 2012). 


\section{Wound healing activity}

Govindarajan et al. (2004) and Mukherjee et al. (2000) studied the wound healing properties of the powdered rhizomes of C. aromatica incorporated in an ointment of soft white paraffin. The ointment was topically applied to acute wounds on rabbits and resulted in significant wound contraction and complete epithelization within 9-11 days. Similarly, cream formulations of $C$. aromatica rhizome extracts also showed significant wound healing properties when applied externally on excision wounds of Swiss albino mice (Kumar et al., 2009).

\section{Antiepileptic activity}

Nonetheless, the plant also consists of compounds that possess antiepileptic effect which is including androstan-17-one (Kaminski et al., 2005) and linalool (Bahr et al., 2019; SoutoMaior et al., 2017), but the activity is yet to be evaluated using $C$. aromatica extracts or essential oils.

\section{Insect repellent activity}

Apart from pharmacological use, C. aromatica is also extensively studied as a potential insecticide. Lack of sufficient knowledge on plant-based oviposition deterrents lead to the current overuse of synthetic insecticides and insect growth regulators to monitor larval instars of mosquitoes, which are believed to cause resistance to insecticides, environmental contamination, and threats to humans and other species, thus representing significant limitations to their successful employment (Benelli, 2015). Recently, the use of some plantderived products, such as essential oils, has shown to provide safer and effective alternatives to synthetic pesticides and repellents (Alshebly et al., 2017).

A study conducted by Singh et al. (2002) showed that the essential oil of $C$. aromatica possesses a better insecticidal effect against Odontotermes obesus Rhamb. (a pest of sugarcane) than the commercial synthetic insecticides, Thidon and Primoban-20. At a dose of $3 \mu \mathrm{l}$ and $6 \mu \mathrm{l}$, the essential oils of $C$. aromatica showed a percentage mortality rate of $50 \%$ and $100 \%$, respectively, after 2 hours of exposure, whereas Thidon showed a mortality rate of $10 \%$ and $20 \%$, and Primoban-20 showed $10 \%$ and $30 \%$ under the same dose and exposure time, respectively.

Pitasawat et al. (2003) showed that the ethanol extract could provide repellence against Aedes togoi mosquito on human volunteers with $\mathrm{ED}_{50}$ and $\mathrm{ED}_{95}$ values of 0.061 and $1.55 \mathrm{mg} / \mathrm{cm}^{2}$, respectively. The biting protection lasted for 3.5 hours when the extract was applied topically at a concentration of $25 \%(\mathrm{w} / \mathrm{w})$. Neither dermal irritation nor adverse effect was reported on the human volunteers. The ethanolic extract was further shown to provide a protective effect against other mosquito species, including Armigeres subalbatus, Culex quinquefasciatus, and $C x$. tritaeniorhynchus under field conditions.

Choochote et al. (2005) also investigated the antimosquito effects, including larvicidal, adulticidal, and repellent activities, of the hexane rhizome extracts and essential oil of $C$. aromatica against Aedes aegypti mosquitoes. The essential oil showed a significantly higher larvicidal activity $\left(\mathrm{LC}_{50}\right.$ of $\left.36.30 \mathrm{ppm}\right)$ against the 4th instar larvae of $A$. aegypti than that of the hexane extracts $\left(\mathrm{LC}_{50}\right.$ of $\left.57.15 \mathrm{ppm}\right)$. On the other hand, the adulticidal activity of the hexane extract was found to be slightly more effective $\left(\mathrm{LC}_{50}\right.$ of $1.60 \mu \mathrm{g} / \mathrm{mg}$ ) against female $A$. aegypti than the essential oil $\left(\mathrm{LC}_{50}\right.$ of $2.86 \mu \mathrm{g} / \mathrm{mg}$ ). However, these two products showed a significant repellent activity against female adult $A$. aegypti. The hexane extract showed higher repellent period (total protection time of 1 hour) when applied at a concentration of $25 \%$ than that of the essential oil ( 0.5 hours). The phytochemical analysis revealed the presence of xanthorrhizol, 1H-3a, 7-methanoazulene, curcumene, germacrone, and camphor as the major constituents, with the exception of germacrone and camphor that are present only in the essential oils.

\section{CONCLUSION}

This review spotlighted important findings of $C$. aromatica as one of the most medically crucial plant species of the genus Curcuma. The review also justifies the reason for the use of this plant in traditional medicines in India, China, and other Southeast Asian countries. However, scientific findings are still lacking on the in vivo toxicity, clinical trials, and nutritional content of this plant. These findings are crucial to providing immense opportunities for the development of new C. aromatica-based products in pharmaceutical industries and cosmetics.

\section{RECOMMENDATIONS}

It should be emphasized that the medicinal value of C. aromatica has not been scientifically and extensively studied as compared to $C$. longa, which is regular turmeric. This could be due to improper farming practices, habitat destruction, deforestation, and the high demand of the pharmaceutical industry for wild plant sources which make this plant one of the most endangered plant species in many South Asian countries, hence leading to the limited supply of the plant. If these hurdles can be mitigated satisfactorily, $C$. aromatica has the potential to be used for the treatment of various diseases. We believe that both conservation and sustainable use of this plant should not be underestimated. We recommend that conservation strategies, such as in situ and ex situ conservation strategies, should be adequately taken into consideration for the sustainable use and proper harvesting of this medicinal plant. Also, biotechnological approaches, such as micropropagation, molecular markerbased approaches, and tissue culture, are promising alternative approaches to produce high-value medicinal plants, including C. aromatica. These methods may shorten the breeding time of the plant.

Although $C$. aromatica has been extensively used in traditional medicine for the treatment of various ailments and scientifically studied for medicinal use, to our understanding, no commercial product is currently available in the market. This could be due to the safety concern on the systemic administration of $C$. aromatica. Hence, more safety studies are required to prove the medicinal value of $C$. aromatica. We strongly believe that these problems can be extenuated through systematic investigation of the whole plant, including toxicity and clinical studies for safety assessment. 


\section{ACKNOWLEDGMENT}

This work was supported by the Short-Term Grant from Universiti Sains Malaysia (Grant no. 304.PFARMASI.6315110).

\section{CONFLICT OF INTEREST}

Authors declared that there are no conflicts of interest.

\section{REFERENCES}

Adams JD. The use of California sagebrush (Artemisia californica) liniment to control pain. Pharmaceuticals, 2012; 5:1045-53; doi:10.3390/Ph5101045.

Ahmad M, Kamran SH, Mobasher A. Protective effect of crude Curcuma longa and its methanolic extract in alloxanised rabbits. Pak J Pharm Sci, 2014; 27:121-8.

Ahmad S, Ali M, Ansari SH, Ahmed F. Phytoconstituents from the rhizomes of Curcuma aromatica salisb. J Saudi Chem Soc, 2011; 15:287-90; doi:10.1016/J.Jscs.2010.10.011

Ahmed S, Ansari SH, Ali M, Bhatt D, Ansari F. Phytochemical and biological investigations on Curcuma aromatica: a review. Pharmacogn Rev, 2008; 2:151-6.

Ajaiyeoba EO, Sama W, Essien EE, Olayemi JO, Ekundayo O, Walker TM, Setzer WN. Larvicidal activity of turmerone-rich essential oils of Curcuma longa leaf and rhizome from Nigeria on anopheles gambiae. Pharm Biol, 2008; 46:279-82; doi:10.1080/13880200701741138

Ali A, Wang YH, Khan IA. Larvicidal and biting deterrent activity of essential oils of Curcuma longa, Ar-turmerone, and curcuminoids against Aedes aegypti and anopheles Quadrimaculatus (Culicidae: Diptera). J Med Entomol, 2015; 52:979-86; doi:10.1093/Jme/Tjv072

Allegra A, Innao V, Russo S, Gerace D, Alonci A, Musolino C. Anticancer activity of curcumin and its analogues: preclinical and clinical studies. Cancer Invest, 2017; 35:1-22; doi:10.1080/07357907.2016.1247166

Almeida JRGS, Souza GR, Silva JC, Saraiva SRGL, Júnior RGO, Quintans JSS, Barreto RSS, Bonjardim LR, Cavalcanti SCH, Junior LJQ. Borneol, a bicyclic monoterpene alcohol, reduces nociceptive behavior and inflammatory response in mice. Sci. World J, 2013:15; doi:10.1155/2013/808460

Al-Reza SM, Rahman A, Parvin T, Rahman MM, Rahman MS. Chemical composition and antibacterial activities of essential oil and organic extracts of Curcuma aromatica salisb. J Food Saf, 2011; 31:433-8; doi:10.1111/J.1745-4565.2011.00318.X

Al-Reza SM, Rahman A, Sattar MA, Rahman MO, Fida HM. Essential oil composition and antioxidant activities of Curcuma aromatica salisb. Food Chem Toxicol, 2010; 48:1757-60; doi:10.1016/J. Fct.2010.04.008

Alshebly MM, Alqahtani FS, Govindarajan M, Gopinath K, Vijayan P, Benelli G. Toxicity of Ar-curcumene and Epi-B-bisabolol from Hedychium larsenii (Zingiberaceae) essential oil on malaria, chikungunya and Japanese encephalitis mosquito vectors. Ecotoxicol Environ Saf, 2017; 137:149-57; doi:10.1016/J.Ecoenv.2016.11.028

Amaral ACF, Gomes LA, Silva JRDA, Ferreira JLP, Ramos ADS, Rosa MDSS, Vermelho AB, Rodrigues IA. Liposomal formulation of turmerone-rich hexane fractions from Curcuma longa enhances their antileishmanial activity. Biomed Res Int, 2014; 2014:8; doi: $10.1155 / 2014 / 694934$

Angel GR, Menon N, Vimala B, Nambisan B. Essential oil composition of eight starchy Curcuma species. Ind Crops Prod, 2014; 60:233-8; doi:10.1016/J.Indcrop.2014.06.028

Anoop K. Curcuma aromatica salisb: a multifaceted spice. Int J Phytopharm Res, 2015; 6:10-5.

Bagad AS, Joseph JA, Bhaskaran N, Agarwal A. Comparative evaluation of anti-inflammatory activity of curcuminoids, turmerones, and aqueous extract of Curcuma longa. Av Pharmacol Sci, 2013:808; doi: $10.1155 / 2013 / 805756$

Bahr TA, Rodriguez D, Beaumont C, Allred K. The effects of various essential oils on epilepsy and acute seizure: a systematic review. Evid Based Complement Altern Med, 2019:6216745; doi:10.1155/2019/6216745

Bamba Y, Yun YS, Kunugi A, Inoue H. Compounds isolated from Curcuma aromatica salisb. Inhibit human P450 enzymes. J Nat Med, 2011; 65(3-4):583-7; doi:10.1007/S11418-011-0507-0

Beer APZ, Filipova MDJL. Effects of 1,8-cineole on the activity of cyclooxygenase and cyclooxygenase 1 and cyclooxygenase 2 isoforms Nat Prod Chem Res, 2017; 05:253; doi:10.4172/2329-6836.1000253

Benelli G. Plant-borne ovicides in the fight against mosquito vectors of medical and veterinary importance: a systematic review. Parasitol Res, 2015; 114(9):3201-12; doi:10.1007/S00436-015-4656-Z

Campos EVR, Proença PLF, Oliveira JL, Pereira AES, De Morais Ribeiro LN, Fernandes FO, Gonçalves KC, Polanczyk RA, Pasquoto-Stigliani T, Lima R, Melville CC, Della Vechia JF, Andrade DJ, Fraceto LF. Carvacrol and linalool co-loaded in B-Cyclodextrin-Grafted chitosan nanoparticles as sustainable biopesticide aiming pest control. Sci Rep, 2018; 8(1):7623; doi:10.1038/S41598-018-26043-X

Campos MG, Oropeza MV, Villanueva T, Aguilar MI, Delgado $\mathrm{G}$, Ponce HA. Xanthorrhizol induces endothelium-independent relaxation of rat thoracic aorta. Life Sci, 2000; 67:327-33; doi:10.1016/S00243205(00)00619-6

Chai L, Liu BM, Lin X, Li QX, Lai MX. Analysis of compositions of the essential oil from Curcuma Aromatica by gas chromatography-mass spectrometry. Zhong Yao Cai, 2012; 35:1102-4.

Chandran B, Goel A. A randomized, pilot study to assess the efficacy and safety of curcumin in patients with active rheumatoid arthritis. Phytother Res, 2012; 26:1719-25; doi:10.1002/Ptr.4639

Cheeseman KH. Mechanisms and effects of lipid peroxidation. Mol Aspects Med, 1993; 14:191-7; doi:10.1016/0098-2997(93)90005-X

Chen H, Tang X, Liu T, Jing L, Wu J. Zingiberene inhibits in vitro and in vivo human colon cancer cell growth via autophagy induction, suppression of $\mathrm{PI} 3 \mathrm{~K} / \mathrm{AKT} / \mathrm{Mtor}$ pathway and caspase 2 deactivation. J BUON, 2019; 24:1470-5.

Chen W, Lu Y, Wu J, Gao M, Wang A, Xu B. Beta-elemene inhibits melanoma growth and metastasis via suppressing vascular endothelial growth factor-mediated angiogenesis. cancer chemother. Pharmacol, 2011; 67:799-808; doi:10.1007/S00280-010-1378-X

Chen ZY, Guo SS, Cao JQ, Pang X, Geng ZF, Wang Y, Zhang Z, Du SS. Insecticidal and repellent activity of essential oil from Amomum Villosum lour. And its main compounds against two storedproduct insects. Int J Food Prop, 2018; 21:2265-75; doi:10.1080/1094 2912.2018.1508158

Cheng JH, Wu WY, Liu WS, Chang G, Liu YL, Yang ZG, Zhou H. Treatment of 17 cases of patients with primary liver cancer with Curcuma Aromatica oil infused via hepatic artery. Shijie Huaren Xiaohua Zazhi, 1999; 7:92.

Choochote W, Chaiyasit D, Kanjanapothi D, Rattanachanpichai E, Jitpakdi A, Tuetun B, Pitasawat B. Chemical composition and antimosquito potential of rhizome extract and volatile oil derived from Curcuma Aromatica against Aedes aegypti (Diptera: Culicidae). J Vector Ecol, 2005; 30:302-9.

Chopra A, Gayathri R, Priya VV. Cytotoxic activity of zingiberene on human gingival fibroblast cell lines. Drug Invent Today, $2019 ; 12: 488-90$.

Choudhury SN, Ghosh AC, Saikia M, Choudhury M, Leclercq PA. Volatile constituents of the aerial and underground parts of Curcuma Aromatica salisb. From India J Essent Oil Res, 1996; 8:633-8; doi:10.1080 /10412905.1996.9701031 
Chuengsamarn S, Rattanamongkolgul S, Luechapudiporn R, Phisalaphong C, Jirawatnotai S. Curcumin extract for prevention of type 2 diabetes. Diabetes Care, 2012; 35:2121-7; doi:10.2337/Dc12-0116

Chung W, Park J, Kim M. Xanthorrhizol inhibits 12-O-tetradecanoylphorbol-13-acetate-induced acute inflammation and two-stage mouse skin carcinogenesis by blocking the. Academic.Oup.Com, Oxford, UK, 2007.

Dai ZJ, Tang W, Lu WF, Gao J, Kang HF, Ma XB, Min WL, Wang $\mathrm{XJ}, \mathrm{Wu}$ WY. Antiproliferative and apoptotic effects of B-elemene on human hepatoma Hepg2 cells. Cancer Cell Int, 2013; 13: 27; doi:10.1186/14752867-13-27

De Oliveira EF, Tosati JV, Tikekar RV, Monteiro AR, Nitin N. Antimicrobial activity of curcumin in combination with light against Escherichia coli $\mathrm{O} 157: \mathrm{H7}$ and Listeria Innocua: applications for fresh produce sanitation. Postharvest Biol Technol, 2018; 137:86-94; doi:10.1016/J.Postharvbio.2017.11.014

Dhingra OD, Jham GN, Barcelos RC, Mendonça FA, Ghiviriga I. Isolation and identification of the principal fungitoxic component of turmeric essential oil. J Essent Oil Res, 2007; 19:387-91; doi:10.1080/104 12905.2007.9699312

Diastuti H, Maolana Syah Y, Dewi Juliawaty L, Singgih M. Antibacterial activity of germacrane type sesquiterpenes from Curcuma Heyneana rhizomes. Indones J Chem, 2014; 14:32-6; doi:10.22146/ Ijc. 21264

Dong S, Luo X, Liu Y, Zhang M, Li B, Dai W. Diarylheptanoids from the root of Curcuma Aromatica and their antioxidative effects. Phytochem Lett, 2018; 27:148-53; doi:10.1016/J.Phytol.2018.07.021

Dosoky NS, Setzer WN. Chemical composition and biological activities of essential oils of Curcuma species. Nutrients, 2018; 10(9):1196; doi:10.3390/Nu10091196

Egger G. In search of a germ theory equivalent for chronic disease. Prev Chronic Dis, 2012; 9:E95; doi:10.5888/Pcd9.110301

Eigenbrode SD, Trumble JT. Antibiosis to beet armyworm (Spodoptera Exigua) in lycopersicon accessions. Hortscience, 2019; 28:932-4; doi:10.21273/Hortsci.28.9.932

Feng J, Xu M, Huang X, Liu H, Lai M, Wei M. GC-MS analysis of essential oil from Curcuma Aromatica rhizome of different growth periods. Zhong Yao Cai, 2013; 36:1926-9.

Ferreira LAF, Henriques OB, Andreoni AAS, Vital GRF, Campos MMC, Habermehl GG, De Moraes VLG. Antivenom and biological effects of ar-turmerone isolated from Curcuma longa (Zingiberaceae). Toxicon, 1992; 30:1211-8; doi:10.1016/0041-0101(92)90437-A

$\mathrm{Fu}$ JT, Tang L, Li WS, Wang K, Cheng DM, Zhang ZX. Fumigant toxicity and repellence activity of camphor essential oil from Cinnamonum Camphora siebold against solenopsis invicta workers (Hymenoptera:Formicidae). J Insect Sci, 2015; 15:129; doi:10.1093/Jisesa/ Iev112

Fujiwara GM, Annies V, De Oliveira CF, Lara RA, Gabriel MM, Betim FCM, Nadal JM, Farago PV, Dias JFG, Miguel OG, Miguel MD, Marques FA, Zanin SMW. Evaluation of larvicidal activity and ecotoxicity of linalool, methyl cinnamate and methyl cinnamate/linalool in combination against Aedes aegypti. Ecotoxicol Environ Saf, 2017; 139:238-44; doi:10.1016/J.Ecoenv.2017.01.046

Gopichand SRD, Meena RL, Singh MK, Kaul VK, Lal B, Acharya R, Prasad R. Effect of manure and plant spacing on crop growth, yield and oil-quality of Curcuma Aromatica salisb. In mid hill of western himalaya. Ind Crops Prod, 2006; 24(2):105-112; doi:10.1016/J.Indcrop.2005.06.006

Govindarajan R, Vijayakumar M, Rao CV, Shirwaikar A, Mehrotra S, Pushpangadan P. Healing potential of Anogeissus Latifolia for dermal wounds in rats. Acta Pharm, 2004; 54:331-8.

Greenwell M, Rahman PKSM. Medicinal plants: their use in anticancer treatment. Int J Pharm Sci Res, 2015; 6:4103-12; doi:10.13040/ IJPSR.0975-8232.6(10).4103-12

Halliwell B. How to characterise an antioxidant: an update. Biochem Soc Symp, 1995; 61:73-101; doi:10.1042/Bss0610073
Hamdi OAA, Ye LJ, Kamarudin MNA, Hazni H, Paydar M, Looi CY, Shilpi JA, Kadir HA, Awang K. Neuroprotective and antioxidant constituents from Curcuma zedoaria rhizomes. Rec Nat Prod, 2015; 9:349-55. Herath HMIC, Wijayasiriwardene TDCMK, Premakumara GAS. Comparative GC-MS analysis of all Curcuma species grown in Sri Lanka by multivariate test. Ruhuna J Sci, 2017; 8:103; doi:10.4038/Rjs.V8i2.29

Hossain CF, Al-Amin M, Sayem ASM, Siragee IH, Tunan AM, Hassan F, Kabir MM, Sultana GNN. Antinociceptive principle from Curcuma Aeruginosa. BMC Complement Altern Med, 2015; 15:191; doi:10.1186/S12906-015-0720-6

Hou XL, Hayashi-Nakamura E, Takatani-Nakase T, Tanaka K, Takahashi K, Komatsu K, Takahashi K. Curdione plays an important role in the inhibitory effect of Curcuma Aromatica on CYP3A4 in Caco-2 cells. Evid Based Complement Alternat Med, 2011:1-9; doi:10.1093/

Ecam/Nep229

Huang KX, Tao ZM, Zhang AJ, Peng SL, Ding LS. Studies on chemical constituents of Curcuma Aromatica salisb. Zhongguo Zhong Yao Za Zhi, 2000; 25:164.

Huang YQ, Geng XZ, Ye SY, Mo YZ, Wu Kun WK. Comparison on the antiinflammatory, analgesic effects and the acute toxicity of Curcuma Aromatica and C. longa from guizhou. Lishizhen Med Mater Medica Res, 2007; 05:275-82.

Hucklenbroich J, Klein R, Neumaier B, Graf R, Fink G, Schroeter M, Rueger M. Aromatic-turmerone induces neural stem cell proliferation in vitro and in vivo. Stem Cell Res Ther, 2014; 5:100; doi:10.1186/Scrt500

Hwang JK, Shim JS, Baek NI, Pyun YR. Xanthorrhizol: a potential antibacterial agent from Curcuma xanthorrhiza against Streptococcus Mutans. Planta Med, 2000; 66:196-7; doi:10.1055/S-0029-1243135

Iwasaki K, Zheng YW, Murata S, Ito H, Nakayama K, Kurokawa T, Sano N, Nowatari T, Villareal MO, Nagano YN, Isoda H, Matsui H, Ohkohchi N. Anticancer effect of linalool via cancer-specific hydroxyl radical generation in human colon cancer. World J Gastroenterol, 2016; 22:9765-74; doi:10.3748/Wjg.V22.I44.9765

Jabir MS, Taha AA, Sahib UI. Antioxidant activity of linalool Eng Technol J, 2018; 36: 64-7; doi:10.30684/Etj.36.1b.11

Jain A, Parihar DK. Nutritional evaluation of Curcuma species collected from different agro climatic regions of chhattisgarh. Am J Ethnomed, 2017; 04:1-8; doi:10.21767/2348-9502.1000020

Jain SD, Pathak R, Koka SS, Nema R. Evaluation of quality control parameters of Curcuma Aromatica aalisb. J Pharmacogn Phytochem, $2016 ; 5: 51-4$

Jantan I, Raweh SM, Sirat HM, Jamil S, Mohd Yasin YH, Jalil J, Jamal JA. Inhibitory effect of compounds from zingiberaceae species on human platelet aggregation. Phytomedicine, 2008; 15:306-9; doi:10.1016/J Phymed.2007.08.002

Jantan I, Saputri FC, Qaisar MN, Buang F. Correlation between chemical composition of Curcuma Domestica and Curcuma xanthorrhiza and their antioxidant effect on human low-density lipoprotein oxidation. Evid Based Complement Alternat Med, 2012; 2012:438356; doi: $10.1155 / 2012 / 438356$

Jarikasem S, Thubthimthed S, Chawananoraseth $\mathrm{K}$, Suntorntanasat T, Brophy JJ. Essential oils from three Curcuma species collected in Thailand. Acta Hortic, 2005; 675:37-40; doi:10.17660/ Actahortic.2005.675.4

Jayaprakasha GK, Jaganmohan Rao L, Sakariah KK. Antioxidant activities of curcumin, demethoxycurcumin and bisdemethoxycurcumin. Food Chem, 2006; 98:720-4; doi:10.1016/J.FOODCHEM.2005.06.037

Jayaprakasha GK, Jena BS, Negi PS, Sakariah KK. Evaluation of antioxidant activities and antimutagenicity of turmeric oil: a byproduct from curcumin production. Z Naturforsch C J Biosci, 2002; 57:828-35; doi:10.1515/Znc-2002-9-1013

Jiang S, Ling C, Li W, Jiang H, Zhi Q, Jiang M. Molecular mechanisms of anti-cancer activities of B-elemene: targeting hallmarks of cancer. Anticancer Agents Med Chem, 2016; 16:1426-34; doi:10.2174/187 1520616666160211123424 
Jiang Z, Jacob JA, Loganathachetti DS, Nainangu P, Chen B. B-elemene: mechanistic studies on cancer cell interaction and its chemosensitization effect. Front Pharmacol, 2017; 8:105; doi:10.3389/ Fphar.2017.00105

Kaminski RM, Marini H, Kim WJ, Rogawski MA. Anticonvulsant activity of androsterone and etiocholanolone. Epilepsia, 2005; 46:819-27; doi:10.1111/J.1528-1167.2005.00705.X

Kanase V, Khan F. An overview of medicinal value of Curcuma species. Asian J Pharm Clin Res, 2018; 11:40-5; doi:10.22159/Ajpcr.2018. V11i12.28145

Kasai H, Yamane Y, Ikegami KM, Sudo H. Analysis of compounds of Curcuma rhizome using mass spectrometry and investigation of the antioxidant activity of rhizome extracts. Med Aromat Plants, 2019; 08:336; doi:10.35248/2167-0412.19.8.336

Khokra SL, Jain S, Kaushik P, Kaushik D. Anti-inflammatory and aanalgesic studies of essential oils of Vitex Negundo linn. J Biol Act Prod From Nat, 2012; 2(4):239-49; doi:10.1080/22311866.2012.10719131

Kim D, Suh Y, Lee H, Lee Y. Immune activation and antitumor response of ar-turmerone on P388D1 lymphoblast cell implanted tumors. Int J Mol Med, 2013; 31:386-92; doi:10.3892/Ijmm.2012.1196

Kim MB, Kim C, Song Y, Hwang JK. Antihyperglycemic and anti-inflammatory effects of standardized Curcuma xanthorrhiza roxb. Extract and its active compound xanthorrhizol in high-fat diet-induced obese mice. Evid Based Complement Altern Med, 2014:205915; doi:10.1155/2014/205915

Kim MG, Kim SM, Min JH, Kwon OK, Park MH, Park JW, Ahn HI, Hwang JY, Oh SR, Lee JW, Ahn KS. Anti-inflammatory effects of linalool on ovalbumin-induced pulmonary inflammation. Int Immunopharmacol, 2019a; 74:105706; doi:10.1016/J.Intimp.2019.105706

Kim MS, Kim HR, Kim H, Choi SK, Kim CH, Hwang JK, Park $\mathrm{SH}$. Expansion of antibacterial spectrum of xanthorrhizol against gramnegatives in combination with PMBN and food-grade antimicrobials. J Microbiol, 2019b; 57:405-12; doi:10.1007/S12275-019-8511-2

Ko JK, Leung CC. Ginger extract and polaprezinc exert gastroprotective actions by anti-oxidant and growth factor modulating effects in rats. J Gastroenterol Hepatol, 2010; 25:1861-9; doi:10.1111/ J.1440-1746.2010.06347.X

Kordali S, Cakir A, Mavi A, Kilic H, Yildirim A. Screening of chemical composition and antifungal and antioxidant activities of the essential oils from three Turkish Artemisia species. J Agric Food Chem, 2005; 53:1408-16; doi:10.1021/Jf048429n

Kotan R, Kordali S, Cakir A, Kesdek M, Kaya Y, Kilic H. Antimicrobial and insecticidal activities of essential oil isolated from Turkish Salvia Hydrangea DC. ex Benth. Biochem Syst Ecol, 2008; 36:360-8; doi:10.1016/J.BSE.2007.12.003

Kumar A, Chomwal R, Kumar P, Sawal R. Anti inflammatory and wound healing activity of Curcuma Aromatica salisb extract and its formulation. J Chem Pharm Res, 2009; 1:304-10.

Kumar N, Nepali K, Sapra S, Bijjem KRV, Kumar R, Suri OP, Dhar KL. Effect of nitrogen insertion on the antitussive properties of menthol and camphor. Med Chem Res, 2012; 21: 531-7; doi:10.1007/ S00044-011-9560-1

Laude EA, Morice AH, Grattan TJ. The antitussive effects of menthol, camphor and cineole in conscious guinea-pigs. Pulm Pharmacol, 1994; 7:179-84; doi:10.1006/PULP.1994.1021

Lee H. Antimicrobial properties of turmeric (Curcuma longa L.) rhizome-derived ar-turmerone and curcumin. Food Sci Biotechnol, 2006; 15:559-63.

Lee J, Jung Y, Shin JH, Kim HK, Moon BC, Ryu DH, Hwang GS. Secondary metabolite profiling of Curcuma species grown at different locations using GC/TOF and UPLC/Q-TOF MS. Molecules, 2014; 19:9535-51; doi:10.3390/Molecules19079535

Lee SC, Wang SY, Li CC, Liu CT. Anti-inflammatory effect of cinnamaldehyde and linalool from the leaf essential oil of Cinnamomum Osmophloeum kanehira in endotoxin-induced mice. J Food Drug Anal, 2018; 26:211-20; doi:10.1016/J.Jfda.2017.03.006
Lee SK, Hong CH, Huh SK, Kim SS, Oh OJ, Min HY, Park KK, Chung WY, Hwang JK. Suppressive effect of natural sesquiterpenoids on inducible cyclooxygenase (COX-2) and nitric oxide synthase (Inos) activity in mouse macrophage cells. J Environ Pathol Toxicol Oncol, 2002; 21:8; doi:10.1615/Jenvironpatholtoxicoloncol.V21.I2.70

Lekshmi PC, Arimboor R, Indulekha PS, Nirmala Menon A. Turmeric (Curcuma longa L.) volatile oil inhibits key enzymes linked to type 2 diabetes. Int J Food Sci Nutr, 2012; 63:832-4; doi:10.3109/096374 86.2011.607156

Li J, Bian WH, Wan J, Zhou J, Lin Y, Wang JR, Wang ZX, Shen Q, Wang KM. Curdione inhibits proliferation of MCF-7 cells by inducing apoptosis. Asian Pacific J Cancer Prev, 2014; 15:9997-10001; doi:10.7314/ APJCP.2014.15.22.9997

Li XJ, Liang L, Shi HX, Sun XP, Wang J, Zhang LS. Neuroprotective effects of curdione against focal cerebral ischemia reperfusion injury in rats. Neuropsychiatr Dis Treat, 2017; 13:1733-40; doi:10.2147/NDT.S139362

Li Y, Wo JM, Liu Q, Li X, Martin RCG. Chemoprotective effects of Curcuma Aromatica on esophageal carcinogenesis. Ann Surg Oncol, 2009; 16:515-23; doi:10.1245/S10434-008-0228-0

Liao W, Khoo YW, Wen J, Goh K, Wai-Shiu, Wong F. Antioxidative and anti-inflammatory effects of xanthorrhizol on aeroallergensinduced biological responses in vitro and ex vivo. Eur Respir J, 2019; 54:PA4206; doi:10.1183/13993003.Congress-2019.Pa4206

Lim CS, Jin DQ, Mok H, Oh SJ, Lee JU, Hwang JK, Ha I, Han JS. Antioxidant and antiinflammatory activities of xanthorrhizol in hippocampal neurons and primary cultured microglia. J Neurosci Res, 2005; 82:831-8; doi:10.1002/Jnr.20692

Lim MS, Choung SY, Jeong KW. Germacrone inhibits estrogen receptor a-mediated transcription in MCF-7 breast cancer cells. Phyther Res, 2016; 30:2036-43; doi:10.1002/Ptr.5711

Liu AC, Zhao LX, Lou HX. Curcumin alters the pharmacokinetics of warfarin and clopidogrel in wistar rats but has no effect on anticoagulation or antiplatelet aggregation. Planta Med, 2013; 79:971-7; doi:10.1055/S-0032-1328652

Liu J, Zhang Z, Gao J, Xie J, Yang L, Hu S. Downregulation effects of beta-elemene on the levels of plasma endotoxin, serum TNFalpha, and hepatic CD14 expression in rats with liver fibrosis. Front Med, 2011; 5:101-5; doi:10.1007/S11684-011-0111-4

Makabe H, Maru N, Kuwabara A, Kamo T, Hirota M. Antiinflammatory sesquiterpenes from Curcuma zedoaria. Nat Prod Res, 2006; 20:680-5; doi:10.1080/14786410500462900

Maniyar YA, Sriraj, D. Peripheral and central analgesic activity evaluation of ethanolic extract of Vitex Negundo flowers in experimental animals. Int J Basic Clin Pharmacol, 2017; 6(11):2701-6. doi:10.18203/2319-2003.Ijbcp20174791

Marina GD, Kekuda TRP, Sudarshan SJ. Antitussive activity of ethanolic extract of Curcuma Aromatica rhizomes on sulfur dioxide induced cough in mice. Anc Sci Life, 2008; 27:36-40.

Melo MM, Habermehl GG, Oliveira NJF, Nascimento EF, Santos MMB, Lúcia M. Treatment of bothrops alternatus envenomation by Curcuma longa and Calendula Officinalis extracts and Ar-Turmerone. Arq Bras Med Vet E Zootec, 2005; 57: 7-17; doi:10.1590/S010209352005000100002.

Meral I, Yener Z, Kahraman T, Mert N. Effect of Nigella Sativa on glucose concentration, lipid peroxidation, anti-oxidant defence system and liver damage in experimentally-induced diabetic rabbits. J Vet Med Ser A, 2001; 48:593-9; doi:10.1046/J.1439-0442.2001.00393.X

Miri S. Phytochemistry, antioxidant, and lipid peroxidation inhibition of the essential oils of lavandula officinalis L. in Iran. Int J Food Prop, 2018; 21:2550-6; doi:10.1080/10942912.2015.1027921

Mirzahosseinipour M, Khorsandi K, Hosseinzadeh R, Ghazaeian M, Shahidi FK. Antimicrobial photodynamic and wound healing activity of curcumin encapsulated in silica nanoparticles. Photodiagnosis Photodyn Ther, 2020; 29:101639; doi:10.1016/J Pdpdt.2019.101639 
Mizuno Y, Jacob RF, Preston Mason R. Inflammation and the development of atherosclerosis - effects of lipid-lowering therapy. $\mathrm{J}$ Atheroscler Thromb, 2011; 18(5):351-8; doi:10.5551/Jat.7591

Mohanty C, Sahoo SK. Curcumin and its topical formulations for wound healing applications. Drug Discov Today, 2017; 22:1582-92; doi:10.1016/J.Drudis.2017.07.001

Moraes DFC, De Mesquita LSS, Do Amaral FMM, De Sousa Ribeiro MN, Malik S. Anticancer drugs from plants. In: Sonia $M$ (ed.). Biotechnology and production of anti-cancer compounds, Springer International Publishing, Cham, Switzerland, pp. 121-42, 2017; doi:10.1007/978-3-319-53880-8_5

Mukherjee PK, Verpoorte R, Suresh B. Evaluation of in-vivo wound healing activity of Hypericum Patulum (Family: Hypericaceae) leaf extract on different wound model in rats. J Ethnopharmacol, 2000; 70:31521; doi:10.1016/S0378-8741(99)00172-5

Murata S, Shiragami R, Kosugi C, Tezuka T, Yamazaki M, Hirano A, Yoshimura Y, Suzuki M, Shuto K, Ohkohchi N, Koda K. Antitumor effect of 1, 8-cineole against colon cancer. Oncol Rep, 2013; 30:2647-52; doi:10.3892/Or.2013.2763

Naz S, Ilyas S, Parveen Z, Javad S. Chemical analysis of essential oils from turmeric (Curcuma longa) rhizome through GC-MS. Asian J Chem, 2010; 22:3153-8.

Neha B, Tiwari KL, Jadhav SK. Comparative phytochemical screening of bioactive compounds in Curcuma caesia roxb. And Curcuma longa.Pdf. Res J Med Plants, 2013; 7:113-8; doi:10.3923/ Rjmp.2013.113.118

Nguyen MH, Lee SE, Tran TT, Bui CB, Nguyen THN, Vu NBD, Tran TT, Nguyen THP, Nguyen TT, Hadinoto K. A simple strategy to enhance the in vivo wound-healing activity of curcumin in the form of selfassembled nanoparticle complex of curcumin and oligochitosan. Mater Sci Eng C, 2019; 98:54-64; doi:10.1016/J.Msec.2018.12.091

Ning L, Ma H, Jiang Z, Chen L, Li L, Chen Q, Qi H. Curcumol suppresses breast cancer cell metastasis by inhibiting MMP-9 via JNK1/2 and Akt-dependent NF-Kb signaling pathways. Integr Cancer Ther, 2016; 15:216-25; doi:10.1177/1534735416642865

Nurcholis W, Munshif AA, Ambarsari L. Xanthorrhizol contents, a-glucosidase inhibition, and cytotoxic activities in ethyl acetate fraction of Curcuma Zanthorrhiza accessions from Indonesia. Brazilian J Pharmacogn, 2018; 28:44-9; doi:10.1016/J.Bjp.2017.11.001

Obeng-Ofori D, Reichmuth C, Bekele J, Hassanali A. Biological activity of 1,8 cineole, a major component of essential oil of Ocimum Kenyense (ayobangira) against stored product beetles. J Appl Entomol, 1997; 121:237-43; doi:10.1111/J.1439-0418.1997.Tb01399.X

Oh OJ, Min HY, Lee SK. Inhibition of inducible prostaglandin E2 production and cyclooxy-genase-2 expression by curdione from Curcuma zedoaria. Arch Pharm Res, 2007; 30:1236-9; doi:10.1007/BF02980264

Oh S, Han AR, Park HR, Jang EJ, Kim HK, Jeong MG, Song H, Park GH, Seo EK, Hwang ES. Suppression of inflammatory cytokine production by $\mathrm{Ar}$-turmerone isolated from Curcuma Phaeocaulis. Chem Biodivers, 2014; 11:1034-41; doi:10.1002/Cbdv.201300397

Oon SF, Nallappan M, Tee TT, Shohaimi S, Kassim NK, Sa'ariwijaya MSF, Cheah YH. Xanthorrhizol: a review of its pharmacological activities and anticancer properties. Cancer Cell Int, 2015; 15:100; doi:10.1186/S12935-015-0255-4

Pajaro-Castro N, Caballero-Gallardo K, Olivero-Verbel J. Neurotoxic effects of linalool and B-pinene on tribolium castaneum herbst. Molecules, 2017; 22(12):2052; doi:10.3390/Molecules22122052

Pant N, Jain DC, Bhakuni RS, Prajapati V, Tripathi AK, Kumar S. Zederone: a sesquiterpenic keto-dioxide from Curcuma aromatica. Indian J Chem, 2001; 40:87-8.

Pant N, Misra H, Jain DCC. Phytochemical investigation of ethyl acetate extract from Curcuma aromatica Salisb. Rhizomes. Arab J Chem, 2013; 6:279-83; doi:10.1016/J.Arabjc.2010.10.007

Park SY, Kim YH, Kim Y, Lee SJ. Aromatic-turmerone attenuates invasion and expression of MMP-9 and COX-2 through inhibition of NF-
$\mathrm{Kb}$ activation in TPA-induced breast cancer cells. J Cell Biochem, 2012; 113:3653-62; doi:10.1002/Jcb.24238

Patil VV, Shilpa RS, Avinash SB, Anuradha GS, Dilip VM, Vihang VP, Shilpa RS, Avinash SB, Anuradha GS, Dilip VM. Phytochemical analysis and antibacterial evaluation of Curcuma longa and Curcuma aromatica against enteric poultry pathogens. Int J Pharm Sci Res, 2019; 10:2000-3; doi:10.13040/IJPSR.0975-8232.10(4).2000-03

Peana AT, D'Aquila PS, Panin F, Serra G, Pippia P, Moretti MDL. Anti-inflammatory activity of linalool and linalyl acetate constituents of essential oils. Phytomedicine, 2002; 9:721-6; doi:10.1078/094471102321621322

Peng WL, Zhong S, Yan Y, Jiang M. Study on the antimicrobial activity of essential oils from Cinnamomum Camphora wood. In: Proceedings - 2012 International Conference on Biomedical Engineering and Biotechnology, ICBEB, 2012, Barcelona, Spain, 2012, pp. 1742-4; doi:10.1109/Icbeb.2012.380

Perrone D, Ardito F, Giannatempo G, Dioguardi M, Troiano G, Lo Russo L, De Lillo A, Laino L, Lo Muzio L. Biological and therapeutic activities, and anticancer properties of curcumin (Review). Exp Ther Med, 2015; 10:1615-23; doi:10.3892/Etm.2015.2749

Pintatum A, Maneerat W, Logie E, Tuenter E, Sakavitsi ME, Pieters L, Berghe WV, Sripisut T, Deachathai S, Laphookhieo S. In vitro anti-inflammatory, anti-oxidant, and cytotoxic activities of four curcuma species and the isolation of compounds from Curcuma aromatica rhizome. Biomolecules, 2020; 10:799; doi:10.3390/Biom10050799

Pitasawat B, Choochote W, Tuetun B, Tippawangkosol P, Kanjanapothi D, Jitpakdi A, Riyong D. Repellency of aromatic turmeric Curcuma aromatica under laboratory and field conditions. J Vector Ecol, 2003; 28(2):234-40.

Pranav Kumar AVR, Deepak SK, Beura S, Sreenivas Reddy GR, Uday Bhasker Goud G, Potbhare MS. Comparative evaluation of effect of extracting solvents on therapeutic activities of Curcuma aromatica rhizomes. Iran J Pharm Sci, 2013; 9:83-97.

Preethi TP, Shinija K, Rakhi KP, Sabu M, Madhusoodanan PV, Benjamin S. Micropropagation and chemical profiling of Curcuma aromatica. J Trop Med Plants, 2010; 11:65-70.

Priyanka R, Vasundhara M, Ah MR. Chemo-profiling of Curcuma aromatica salisbury rhizomes and leaves from South India. J Med Plants Stud, 2019; 7:260-2.

Promod D. Pharmacognostical and phytochemical analysis of vanya haridra (Curcuma aromatica Salisb.) Rhizomes. Int J Ayurvedic Herb Med, 2018; 3:3213-22; doi:10.31142/Ijahm/V8i3.03

Queiroga CL, Teixeira Duarte MC, Baesa Ribeiro B, De Magalhães PM. Linalool production from the leaves pf Bursera Aloexylon and its antimicrobial activity. Fitoterapia, 2007; 78:327-8; doi:10.1016/J. Fitote.2007.03.012

Quintans-Júnior L, Moreira JCF, Pasquali MAB, Rabie SMS Pires AS, Schröder R, Rabelo TK, Santos JPA, Lima PSS, Cavalcanti $\mathrm{SCH}$, Araújo AAS, Quintans JSS, Gelain DP. Antinociceptive activity and redox profile of the monoterpenes. Int Sch Res Notices, 2013; 2013:11; doi: $10.1155 / 2013 / 459530$

Raafat KM, Omar AG. Phytotherapeutic activity of curcumol: isolation, $\mathrm{GC}-\mathrm{MS}$ identification, and assessing potentials against acute and subchronic hyperglycemia, tactile allodynia, and hyperalgesia. Pharm Biol, 2016; 54:1334-44; doi:10.3109/13880209.2015.1077463

Rahimi-Nasrabadi M, Nazarian S, Farahani H, Fallah Koohbijari GR, Ahmadi F, Batooli H. Chemical composition, antioxidant, and antibacterial activities of the essential oil and methanol extracts of Eucalyptus Largiflorens F. Muell Int J Food Prop, 2013; 16:369-81; doi:10.1080/10942912.2010.551310.

Rahman FA, Priya V, Gayathri R, Geetha RV. In vitro antibacterial activity of camphor oil against oral microbes. Int J Pharm Sci Rev Res, 2016; 39:119-21.

Rajkumari S, Sanatombi K. Nutritional value, phytochemical composition, and biological activities of edible Curcuma species: a review. Int J Food Prop, 2018; 20:S2668-87; doi:10.1080/10942912.2017.1387556 
Ramkumar M, Rajasankar S, Gobi VV, Dhanalakshmi C, Manivasagam T, Justin Thenmozhi A, Essa MM, Kalandar A, Chidambaram R. Neuroprotective effect of demethoxycurcumin, a natural derivative of curcumin on rotenone induced neurotoxicity in SH-SY $5 \mathrm{Y}$ neuroblastoma cells. BMC Complement Altern Med, 2017; 17:217; doi:10.1186/S12906$017-1720-5$

Ramkumar M, Rajasankar S, Gobi VV, Janakiraman U, Manivasagam T, Thenmozhi AJ, Essa MM, Chidambaram R, Chidambaram SB, Guillemin GJ, Demethoxycurcumin, a natural derivative of curcumin abrogates rotenone-induced dopamine depletion and motor deficits by its antioxidative and anti-inflammatory properties in parkinsonian rats. Pharmacogn Mag, 2018; 14:9-16; doi:10.4103/Pm.Pm_113_17

Rana M, Reddy SS, Maurya P, Singh V, Chaturvedi S, Kaur K, Agarwal H, Ahmad H, Naqvi A, Dwivedi AK, Dikshit M, Barthwal MK. Turmerone enriched standardized Curcuma longa extract alleviates LPS induced inflammation and cytokine production by regulating TLR4 IRAK1-ROS-MAPK-Nfikb Axis. J Funct Foods, 2015; 16:152-63; doi:10.1016/J.JFF.2015.04.034

Ravindran N, Nirmal K, Sivaraman K. Tumeric the genus Curcuma. CRC Press, London, UK, 2007.

Revathi S, Malathy NS. Antibacterial activity of rhizome of Curcuma aromatica and partial purification of active compounds. Indian $\mathrm{J}$ Pharm Sci, 2013; 75:732-5.

Rodenak-Kladniew B, Castro A, Stärkel P, De Saeger C, García De Bravo M, Crespo R. Linalool induces cell cycle arrest and apoptosis in Hepg2 cells through oxidative stress generation and modulation of Ras/ MAPK and Akt/Mtor pathways. Life Sci, 2018; 199:48-59; doi:10.1016/J. Lfs.2018.03.006

Roxo DF, Arcaro CA, Gutierres VO, Costa MC, Oliveira JO, Lima TFO, Assis RP, Brunetti IL, Baviera AM. Curcumin combined with metformin decreases glycemia and dyslipidemia, and increases paraoxonase activity in diabetic rats. Diabetol Metab Syndr, 2019; 11:33; doi:10.1186/ S13098-019-0431-0

Rukayadi Y, Hwang JK. In vitro anti-malassezia activity of xanthorrhizol isolated from Curcuma xanthorrhiza Roxb. Lett Appl Microbiol, 2007; 44:126-30; doi:10.1111/J.1472-765X.2006.02062.X

Rukayadi Y, Yong D, Hwang JK. In vitro anticandidal activity of xanthorrhizol isolated from Curcuma xanthorrhiza Roxb. J Antimicrob Chemother, 2006; 57: 1231-4; doi:10.1093/Jac/Dk1132

Saito Y, Shiga A, Yoshida Y, Furuhashi T, Fujita Y, Niki E. Effects of a novel gaseous antioxidative system containing a rosemary extract on the oxidation induced by nitrogen dioxide and ultraviolet radiation. Biosci Biotechnol Biochem, 2004; 68:781-6; doi:10.1271/Bbb.68.781

Sampath S, Veeramani V, Krishnakumar GS, Sivalingam U, Madurai SL, Chellan R. Evaluation of in vitro anticancer activity of 1,8-Cineole-Containing N-Hexane extract of Callistemon Citrinus (Curtis) skeels plant and its apoptotic potential. Biomed Pharmacother, 2017; 93:296-307; doi:10.1016/J.Biopha.2017.06.056

Saxena J, Sahu R. Evaluation of phytochemical constituent in conventional and non conventional species of Curcuma. Int Res J Pharm, $2012 ; 3: 203-4$

Schmidt E, Ryabchenko B, Wanner J, Jager W, Jirovetz L. Cytotoxic active constituents of essential oils of Curcuma longa and Curcuma Zanthorrhiza. Nat Prod Commun, 2015; 10:139-41.

Schultes RE. Cornucopia: a source book of Edible plants. J Ethnopharmacol, 1991; 34:291-2; doi:10.1016/0378-8741(91)90056-J

Seema, Kaur, P. Comparative study of pharmacognostical and preliminary phytochemical investigation of Curcuma longa leaves and rhizomes. Imp J Interdiscip Res, 2016; 2:1677-82.

Shivalingu BR, Vivek HK, Priya BS, Soujanya KN, Swamy SN. Purification and characterization of novel fibrin(ogen)olytic protease from Curcuma aromatica salisb.: role in hemostasis. Phytomedicine, 2016; 23:1691-8; doi:10.1016/J.Phymed.2016.09.007

Sikha A, Harini A, Hegde Prakash L. Pharmacological activities of wild turmeric (Curcuma aromatica Salisb): a review. J Pharmacogn Phytochem, 2015; 3:1-4.
Singh G, Singh OP, Maurya S. Chemical and biocidal investigations on essential oils of some indian Curcuma species. Prog Cryst Growth Charact Mater, 2002; 45:75-81; doi:10.1016/S09608974(02)00030-X.

Souto-Maior FN, Da Fonsêca DV, Salgado PRR, Monte L, De O, De Sousa DP, De Almeida, RN. Antinociceptive and anticonvulsant effects of the monoterpene linalool oxide. Pharm Biol, 2017; 55: 63-7; doi10.108 $0 / 13880209.2016 .1228682$

Srividya AR, Dhanabal P, Bavadia P, Vishnuvarthan VJ, Sathish Kumar MN. Antioxidant and antidiabetic activity of Curcuma aromatica. Int J Res Ayurveda Pharm, 2012; 3:401-5.

Sun XB, Wang SM, Li T, Yang YQ. Anticancer activity of linalool terpenoid: apoptosis induction and cell cycle arrest in prostate cancer cells. Trop J Pharm Res, 2015; 14:619-25; doi:10.4314/Tjpr. V14i4.9

Tabari MA, Youssefi MR, Maggi F, Benelli G. Toxic and repellent activity of selected monoterpenoids (thymol, carvacrol and linalool) against the castor bean tick, Ixodes Ricinus (Acari: Ixodidae). Vet Parasitol, 2017; 245:86-91; doi:10.1016/J.Vetpar.2017.08.012

Takaishi M, Fujita F, Uchida K, Yamamoto S, Shimizu MS, Uotsu CH, Shimizu M, Tominaga M. 1,8-Cineole, A TRPM8 Agonist, Is A Novel Natural Antagonist Of Human TRPA1. Mol Pain, 2012; 8:1-12; doi:10.1186/1744-8069-8-86.

Togar B, Türkez H, Stefano A, Tatar A, Cetin D. Zingiberene attenuates hydrogen peroxide-induced toxicity in neuronal cells. Hum Exp Toxicol, 2015; 34:135-44; doi:10.1177/0960327114538987

Torres-Martínez R, García-Rodríguez YM, Ríos-Chávez P, Saavedra-Molina A, López-Meza JE, Ochoa-Zarzosa A, Garciglia RS. Antioxidant activity of the essential oil and its major terpenes of Satureja Macrostema (Moc. And Sessé Ex Benth.) Briq Pharmacogn Mag, 2017; 13:S875-80; doi:10.4103/Pm.Pm-316-17

Tsai ML, Wu CT, Lin TF, Lin WC, Huang YC, Yang CH. Chemical composition and biological properties of essential oils of two mint species. Trop J Pharm Res, 2018; 12:577-82. doi:10.4314/tjpr.v12i4.20

Tsai SY, Huang SJ, Chyau CC, Tsai CH, Weng CC, Mau JL. Composition and antioxidant properties of essential oils from Curcuma Rhizome. Asian J Arts Sci, 2011; 2:57-66.

Tyagi P, Singh M, Kumari H, Kumari A, Mukhopadhyay K. Bactericidal activity of curcumin $\mathrm{I}$ is associated with damaging of bacterial membrane. PloS One, 2015; 10(3):e0121313; doi:10.1371/Journal. Pone. 0121313

Vallianou I, Peroulis N, Pantazis P, Hadzopoulou-Cladaras M. Camphene, a plant-derived monoterpene, reduces plasma cholesterol and triglycerides in hyperlipidemic rats independently of HMG-Coa reductase activity. PloS One, 2011; 6:E20516; doi:10.1371/JOURNAL. PONE.0020516

Vallianou NG, Evangelopoulos A, Schizas N, Kazazis C Potential anticancer properties and mechanisms of action of curcumin. Anticancer Res, 2015; 35:645-51.

Van Zyl, RL, Seatlholo ST, Van Vuuren SF, Viljoen AM. The biological activities of 20 nature identical essential oil constituents. J Essent Oil Res, 2006; 18:129-33; doi:10.1080/10412905.2006.12067134.

Viljoen A, Van Vuuren S, Ernst E, Klepser M, Demirci B, Başer H, Van Wyk B-E. Osmitopsis Asteriscoides (Asteraceae)-the antimicrobial activity and essential oil composition of a Cape-Dutch remedy. J Ethnopharmacol, 2003; 88:137-43; doi:10.1016/S0378-8741(03)00191-0

Widowati W, Wargasetia TL, Afifah E, Mozef T, Kusuma HSW, Nufus H, Arumwardana S, Amalia A, Rizal R. Antioxidant and antidiabetic potential of Curcuma longa and its compounds. Asian J Agric Biol, 2018; 6:149-61.

Wu J, Feng Y, Han C, Huang W, Shen Z, Yang M, Chen W, Ye L. Germacrone derivatives: synthesis, biological activity, molecular docking studies and molecular dynamics simulations. Oncotarget, 2017; 8:1514958; doi:10.18632/Oncotarget.14832

Wu K, Lin Y, Chai X, Duan X, Zhao X, Chun C. Mechanisms of vapor-phase antibacterial action of essential oil from Cinnamomum 
Camphora var. linaloofera fujita against Escherichia coli. Food Sci Nutr, 2019; 7:2546-55; doi:10.1002/Fsn3.1104.

Wu L, Wang L, Tian X, Zhang J, Feng, H. Germacrone exerts anti-cancer effects on gastric cancer through induction of cell cycle arrest and promotion of apoptosis. BMC Complement Med Ther, 2020; 20(1):21; doi:10.1186/S12906-019-2810-3

Wu ZL, Du YH, Guo ZF, Lei KJ, Jia YM, Xie M, Kang X, Wei Q, He L, Wang Y, Hu Y, Yuan M, Yuan S. Essential oil and its major compounds from oil camphor inhibit human lung and breast cancer cell growth by cell-cycle arresting. Int J Clin Exp Med, 2016; 9:12852-61.

Xiang H, Zhang L, Xi L, Yang Y, Wang X, Lei D, Zheng X, Liu $\mathrm{X}$. Phytochemical profiles and bioactivities of essential oils extracted from seven Curcuma herbs. Ind Crops Prod, 2018; 111:298-305; doi:10.1016/J. Indcrop.2017.10.035

Xiang H, Zhang L, Yang Z, Chen F, Zheng X, Liu X. Chemical compositions, antioxidative, antimicrobial, anti-inflammatory and antitumor activities of Curcuma aromatica salisb. Essential Oils. Ind Crops Prod, 2017; 108:6-16; doi:10.1016/J.Indcrop.2017.05.058.

Xiong ZY, Xiao FM, Xu X, Wu YF, Jiang XM. Studies on pharmacological activity of borneol. Zhongguo Zhong Yao Za Zhi, 2013; 38:786-90.

Yanti, Rukayadi Y, Lee K, Han S, Hwang JK. Anti-biofilm activity of xanthorrhizol isolated from Curcuma xanthorrhiza roxb. Against bacterial biofilms formed by saliva and artificial multi-species oral strains. Food Sci Biotechnol, 2009; 18:556-60.

Ye L, Wu J, Chen W, Feng Y, Shen Z. Novel anti-cancer agents based on germacrone: design, synthesis, biological activity, docking studies and MD simulations. RSC Adv, 2017; 7:3760-7; doi:10.1039/C6ra26944c

Yu J, Zhou X, He X, Dai M, Zhang Q. Curcumin induces apoptosis involving Bax/Bcl-2 in human hepatoma SMMC-7721 cells. Asian Pac J Cancer Prev, 2011; 12:1925-9.

Yue GGL, Chan BCL, Hon PM, Lee MYH, Fung KP, Leung PC, Lau CBS, Evaluation of in vitro anti-proliferative and immunomodulatory activities of compounds isolated from Curcuma longa. Food Chem Toxicol, 2010; 48:2011-20; doi:10.1016/J.Fct.2010.04.039

Zafar MMI, Hassan F, Naqvi SBS, Muhammad S, Hasan F, Jabeen S, Israr F. Evaluation of antibacterial activity of camphor, benzoin, cubebs, fenugreek, apricot and cinnamon leaf against standard cultures and clinical isolates of an array of organisms. Pak J Pharmacol, 2019; 36:69-75.
Zhang R, Hao J, Guo K, Liu W, Yao F, Wu Q, Liu C, Wang Q, Yang X. Germacrone inhibits cell proliferation and induces apoptosis in human esophageal squamous cell carcinoma cells. Biomed Res Int, 2020 2020:13; doi:10.1155/2020/7643248

Zhang W, Wang Z, Chen T. Curcumol induces apoptosis via caspases-independent mitochondrial pathway in human lung adenocarcinoma ASTC-A-1 cells. Med Oncol, 2011; 28:307-14; doi:10.1007/S12032-010-9431-5.

Zhang Y, Wang Y, Zhao Y, Gu W, Zhu Y, Wang S. Novel camphor-based pyrimidine derivatives induced cancer cell death through a ROS-mediated mitochondrial apoptosis pathway. RSC Adv, 2019; 9:2971120; doi:10.1039/C9ra05900h

Zhao J, Zhang J, Yang B, Lv G-P, Li S-P. Free radical scavenging activity and characterization of sesquiterpenoids in four species of Curcuma using a TLC bioautography assay and GC-MS analysis. Mol, 2010; 15:7547-57; doi:10.3390/MOLECULES15117547

Zhao SY, Wu J, Zheng F, Tang Q, Yang LJ, Li L, Wu WY, Hann SS. B-elemene inhibited expression of DNA methyltransferase 1 through activation of ERK1/2 and ampk $\alpha$ signalling pathways in human lung cancer cells: the role of sp1. J Cell Mol Med, 2015; 19:630-41; doi:10.1111/ Jcmm. 12476

Zheng XB, Zhang YL, Li Q, Liu YG, Wang XD, Yang BL, Zhu GC, Zhou CF, Gao Y, Liu ZX. Effects of 1,8-cineole on neuropathic pain mediated by P2X2 receptor in the spinal cord dorsal horn. Sci Rep, 2019; 9:1-8; doi:10.1038/S41598-019-44282-4

How to cite this article:

Umar NM, Parumasivam T, Aminu N, Toh SM. Phytochemical and pharmacological properties of Curcuma aromatica Salisb (wild turmeric). J Appl Pharm Sci, 2020; 10(10): 180-194. 